\title{
Governance Quality and Tax Compliance Behaviour in East Malaysia
}

\author{
MOHD ALLIF ANWAR ABU BAKAR \& MOHD RIZAL PALIL \& RUHANITA MAELAH
}

\begin{abstract}
In this paper, we examine the relationship and links between the governance quality and tax compliance behaviour across taxpayers in East Malaysia otherwise known as Borneo. The hypotheses were tested using structural equation modelling of partial least squares. Four proxies of governance quality were examined in the study, namely, Voice and Accountability (VA), Political Stability (PS), Government Effectiveness (GE), and Rule of Law (RL). Results indicate that only political stability and rule of law are found to significantly influence tax compliance behaviour positively, while the other two proxies of voice and accountability and government effectiveness showed otherwise with insignificant findings. The current finding suggests that the government should maintain stability in the political system and promote a stringent with the effective rule of law to encourage substantial participation in tax compliance behaviour.
\end{abstract}

Keywords: Governance quality; tax compliance; taxpayers; East Malaysia

\section{INTRODUCTION}

In most developing countries, governments face numerous challenges to raise tax collections. Although governments have implemented many ways of tax reformation over the years to curb the issue of non-compliance, prior evidence still shows a low level of tax compliance. Internationally, Benk et al. (2015) reported tax evasion as relatively serious and ranked it at number 10 out of 21 offences surveyed, in support the work of Karlinsky, Burton, \& Blanthorne (2004) in the United States which also reported tax evasion as somehat serious. Karlinsky, Burton, \& Blanthorne (2004) ranked tax evasion after the accounting fraud, violation of child labour and insider trading. In Malaysia, mainly, The Inland Revenue Board of Malaysia (IRBM) addresses the low statistics level of tax compliance among Malaysians. Among the total of 14.9 million labour force in Malaysia, only 2.27 million individuals paid tax in 2018 (The Edge 2018). This small number should not be overlooked, especially that IRBM has also identified 79,786 individuals, companies, and organisations with extraordinary wealth but fail to report correct tax amount (The Star 2018).

The notion of governance in the study is associated with the engagement between the government's performance and civil societies. The most widely used concept to reflect governance is the definition of "quality of government" by World Bank, that is, "the traditions and institutions by which authority in a country is exercised" (Kaufmann et al. 2011, p. 222). Hence, governments are demanded by their citizens to be responsible and accountable for any of their fiscal and national policy implementation. Many scholars recently discuss the quality of government because it specifically draws concerns about the benefits that it provides to enhance tax collection (e.g., Torgler et al. 2007; Cummings et al. 2009; Gangl et al. 2013; Forteza \& Noboa 2019). With these ideas in mind, the scepticism about governance motivates us to extend the study that can help in explaining why citizens justify their compliance behaviour with taxes. This argument may emerge as a sense of reciprocity: for example, would I pay my taxes if the government is ineffective, injustice or corrupt? Thus, the question of the link between governance quality and tax compliance is raised. Citizens fund government operations by paying taxes. Therefore, any government action is of the interest to taxpayers.

Over the last five decades, the literature on tax compliance suffers from few limitations, thus making the current research differs from prior studies in a few main areas. At first sight, most previous studies view tax compliance problems from the perspective of the economic deterrence model (Riahi-Belkaoui 2004). This model emanates from Allingham and Sandmo (1972) the neoclassical tax model that assumes that taxpayers' decision on whether or not to pay taxes relies on their expected behaviour in balancing after-tax returns (benefits) and risks (costs). Their deterrence or economic approach model posits that compliance largely depends on tax audit and penalty. However, this model has been criticised due to its failure in yielding right prediction of taxpayer behaviour (Devos 2012; Organisation for Economic Co-operation and Development (OECD) 2010; Torgler 2004).

Thus, recent literature focuses on other non-economic factors that contribute to compliance, such as trust in authorities (Kastlunger et al. 2013; Gangl et al. 2015; Chong \& Arunachalam 2018; Batrancea et al. 2019; Farrar et al. 2020), personal and social norms (Gobena \& Van Dijke 2016; Jimenez \& Iyer 2016; Hallsworth et al. 2017) and social and psychological perspectives (Organisation for Economic Co-operation and Development (OECD) 2004; Torgler 2007). Nonetheless, Slemrod (2019) in his latest work, also call for behavioural considerations to be incorporated in the tax compliance model. Despite that many researchers extend the variation of the deterrence model, little attention is given to the influence of taxpayers' perceptions about institutional factors, particularly governance quality because citizens live and coexist in the system governed by an institution.

Secondly, the influence of governance may be geographically concentrated depending on the performance of government in the respective countries. For instance, Wang (2010) discovered that Australians, followed by Chinese and 
Japanese, are most satisfied with their governments' performance, whereas Americans and Russians display little differences. Yet, Sen (2014) found that the governance quality in Asia is lower than that in other regions in the world (except in sub-Saharan Africa). Thus, the relationship between governance quality and tax compliance, in this case, Malaysia, is interesting to examine since government performance differs between states and countries. To date, tax literature which link the perception of governance quality and tax compliance in Malaysia is far less often, specifically in East Malaysia that is mostly non-existent, thereby open the possibility to quest for the answers.

Finally, contrary to previous studies, which use Worldwide Governance Indicators (WGI) as their main index in governance quality (e.g., Torgler et al. 2007; Cummings et al. 2009; Rodriguez-Justicia \& Theilen 2018; Mohammed Abdullahi Umar et al. 2019), the present study considers taxpayers individually to assess their perception of governance in East Malaysia. Although the governance index undoubtedly encompasses an overall aspect of governance at the macrolevel (in this case Malaysia), the index may not precisely represent the perception on a sample from individual taxpayers, given that the current study focuses on the East Malaysia region alone. In the same stand, Forteza \& Noboa (2019) also measure the quality of government in response to the own individual perception on institutional quality namely confidence in government, confidence in civil service and confidence in justice.

Therefore, this study argues that the relationship between governance quality and taxpayers should be understood, mostly on how and why citizens agree to pay tax and on how and why they abstain from paying tax. In doing so, as a starting point, developing and testing a direct effect within the ambit of governance quality and tax compliance will allow the study to report theoretical correlation among variables, hence contributing to the theory development. This study undertakes empirical research with the primary objective of investigating whether better governance quality leads to improved tax compliance or otherwise. In the context of this study, governance quality is considered by means of taxpayers' perceptions on four proxies borrowed from the World Bank's governance measures, namely, voice and accountability, political stability, government effectiveness, and the rule of law. The study's contributions are described as follows:

1. to extend the work of tax compliance model by including governance as contributing factors. Taxpayers observe the performance of the government, and any action by the government will mostly matter to taxpayers since they live and coexist within a system governed by an institution;

2. to enriches the existing literature of governance quality within the ambit of tax compliance model. Although the current framework of governance has been previously tested in other countries, none of the similar studies has been conducted in East Malaysia;

3. the use of survey perception on governance quality is deemed more appropriate than the governance index itself as the measures cater the taxpayers' opinion concentrated geographically alone for the East Malaysia, rather than to include Index which summarised level of governance quality at the national level.

The remainder of the paper is presented as follows: Section 2 deals with the literature review and hypothesis development. Section 3 shows the overview of the methodology of the study, research framework, and measurement of variables. Section 4 reports and discusses the results. Section 5 lists the theoretical and practical contributions, along with the concluding remarks.

\title{
THEORETICAL FRAMEWORK AND HYPOTHESIS DEVELOPMENT
}

\author{
GOVERNANCE QUALITY AND TAX COMPLIANCE
}

The nexus between governance and tax compliance has emerged as a non-economic approach that recognises the existence of a social relationship between the citizens and the government. Earlier, Levi (1989) agreed that the relationship between taxpayer and government could be clarified through a vertical contract of quid pro quo of taxation, which later supported by Besançon (2003). Da Cruz \& Marques (2017) argue that quality of governance is linked to the actual practices of government, with "good governance" indicates the fulfilment of above certain criteria target ("Good" level), while "bad governance" correlate to governance level that is below than what is required/ threshold ("Neutral" level).

From the tax point of view, legitimacy theory holds that taxpayers behave by observing the behaviour of their government, particularly on how it provides services in exchange for paid taxes. The centric to legitimacy theory is the social contract within the concept of fiscal exchange, which assumes that the behaviour of citizens is motivated by the efforts of the government. In our conception, any actions of the government to implement, develop and communicate its social responsibility, should and ultimately consider the rights of the taxpayer at large, or else sanction may be imposed by the taxpayer in the form of non-compliance for failing to meet their expectation.

In this regard, any government action may compromise compliance, which has been well discussed in another discipline of economics and political science (Fjeldstad et al. 2012; Slemrod 2019). For example, government objectives that are aligned with citizens' interest (goal congruence) increase tax compliance (Picur \& Riahi-Belkaoui 2006; Torgler et 
al. 2007). In this study, taxpayers' perception of governance is measured across four proxies, as shown in the following discussion.

\section{VOICE AND ACCOUNTABILITY AND TAX COMPLIANCE}

Taxpayers perceive that their voices should be heard to represent their participation in governmental policy, that is, the government should be accountable for any of their actions, with a view that power has been entrusted to them through public approval. In taxation setting, taxpayers' significant participation in policymaking by democratic means increases individuals' willingness to pay taxes because of the trust-based relationship between governments and taxpayers (Torgler 2003). This finding is supported by Everest-Phillip and Sandall (2009). They advocated that taxpayers' willingness to pay tax is dependent upon the public perception of government accountability in the form of provision of public goods and services.

Besides, citizens' rationalisation of non-compliance is thwarted if they are allowed to have voice and require accountability (for instance, in the form of respect for human rights) (Nkundabanyanga et al. 2017). In the same stand, Casal et al. (2016) also support the position of increasing tax compliance if citizens' were allowed to have a voice on tax contributions. Modugu et al. (2012) stated that if governments are considered accountable, many people will voluntarily pay their taxes, thus reducing the need for coercion. However, if governments are perceived as unaccountable, any demand (for example new or increase taxes) is retaliated with protest and violence. Prior-mentioned studies provide the necessary grounds for the following hypothesis:

$\mathrm{H}_{1} \quad$ Voice and accountability are positively related to tax compliance.

\section{POLITICAL STABILITY AND TAX COMPLIANCE}

Aizenman and Jinjarak (2008) linked tax collection performance with political stability and conjectured that political stability is the most essential variable in developing countries compared with high-income countries. They reported that political stability significantly increases tax collection efficiency and the resources devoted to tax enforcement, ultimately causing high tax compliance. This finding is consistent with Damania et al. (2004), who revealed that political instability only weakens judicial efficiency, which in turn causes corruption to become pervasive. In such countries, the compliance level with regulation is also low. However, Tedds (2010) reported differently; that is, political instability does not affect the underreporting of tax but posited that political instability might limit the ability of a country to collect the tax. In Malaysia, the dilemma has become prominent due to political unrest with drastic changes of government and prime minister within only two years, from 2018 to 2020. Drawing from these notions, the following hypothesis is established.

$\mathrm{H}_{2} \quad$ Political stability is positively related to tax compliance.

\section{GOVERNMENT EFFECTIVENESS AND TAX COMPLIANCE}

Government effectiveness can be translated as the capability of governments to satisfy the expectation of citizens in terms of public goods and services or political goods. Lassen (2007) argued that if the combination of political goods supplied by governments dramatically differs from the preference of the taxpayers, then taxpayers may exhibit a reduction in the attractiveness of the quid pro quo contract, which can lead to low tax compliance. Alm and Gomez (2008) supported this argumentation with a positive association between taxpayers' perception of the benefits derived from political goods and their willingness to abide by tax laws. If a country practices an effective tax administration, then the willingness to pay tax is also tacitly increased (Everest-Phillip and Sandall 2009). In Latin America, taxpayers likely pay taxes if they notice that their government is performing well (Ortega et al. 2016). Nkundabanyanga et al. (2017) also demonstrated that when a government is efficient (for example, in the context of implementing successful public financial management systems), non-compliance is likely impaired. Thus, the present study formulates the following hypothesis:

$\mathrm{H}_{3} \quad$ Government effectiveness is positively related to tax compliance.

\section{RULE OF LAW AND TAX COMPLIANCE}

According to Torgler and Schneider (2009), the absence of an effective and the efficient rule of law may undermine public readiness to pay tax. On these notions, a country with an established and the effective rule of law is widely perceived and accepted by its people as social norms, thereby showing better compliance than a country without an effective rule of law (Bergman 2009). Based on Twelve Guiding Principles of Good Tax Policy by Association of International Certified Professional Accountants (2017, p. 10), "Taxpayers should readily have access to information for understanding sources and uses of tax revenues. Transparency in the law-making and guidance process helps promote an improved understanding and respect for the system". Mohammed Abdullahi Umar et al. (2019) stated that the willingness to pay tax 
is high because the effective rule of law ensures adequate sanction for non-compliance. This is also corroborated with the latest work of Forteza \& Noboa (2019) which reported a significant negative association between individual confidence in justice and justification to evade taxes. Corresponding to this, the increasing awareness of citizen's perception of lawmaking is vital to create compliance, or else, citizens will blame government ever for a minor mistake. In light of the extant literature, the following hypothesis is established:

$\mathrm{H}_{4} \quad$ The Effective rule of law is positively related to tax compliance.

\section{PROPOSED FRAMEWORK}

Based on the previous discussion, an integrative model, as illustrated in Figure 1, was constructed to test four direct hypotheses. The path illustrates that all taxpayers' perceptions on governance quality (1) voice and accountability, (2) political stability, (3) government effectiveness, and (4) the rule of law are expected to be positively associated with tax compliance ( $\mathrm{H} 1, \mathrm{H} 2, \mathrm{H} 3$, and H4). The current study has also been supported by the legitimacy theory, which suggests that social or fiscal relationship between government and citizens influences perception on governance quality, which in turn affects the tax compliance.

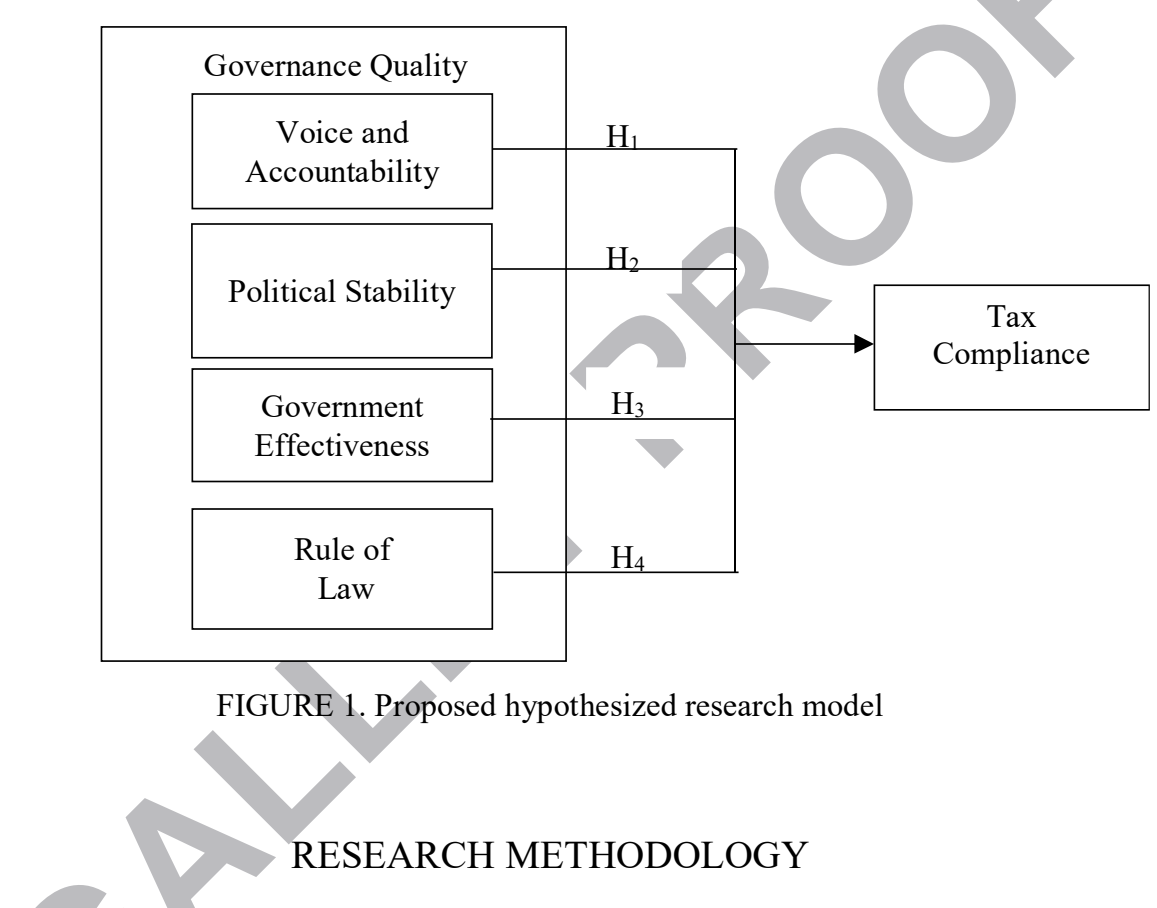

SAMPLE AND DATA COLLECTION

A quantitative approach was used to obtain governance perception in East Malaysia, within the two states of Sabah and Sarawak. Due to time constraints and low administration cost, the study survey was made available online (Evans \& Mathur 2018). Note that with the advances in technology and survey research tools, the benefits of an online survey may outweigh its weakness (for a review see Evans \& Mathur 2005, 2018). Subsequently, Loomis \& Paterson (2018) provided empirical evidence that the result of an online questionnaire is comparable and possibly the same to that of the paper-andpencil questionnaire in terms of response rate, nonresponse item and nature of the data. A total of 78 respondents from salaried and self-employed taxpayers participated in the survey, and data were collected through random sampling to the selected respondents. Following the rule of thumb ten times the largest number of structural paths directed at a particular construct in the structural model, the study satisfies the minimum sample size requirement for Partial Least Square Structural Equation Modelling (PLS-SEM) (Hair et al. 2016). Besides, by utilising the GPower, the study also meets the estimated minimum requirement of 32 cases at four predictors if the effect size $=0.15, \mathrm{Sig}=0.10$ and statistical power $=$ 0.80 . Since the study is a starting point to further extend the governance-tax compliance model, the preliminary analysis of 78 respondents were later justified.

Borneo was selected as the geographical location because research on tax compliance is less conducted in this region than its peers in peninsular Malaysia. Most research on tax matters in Sabah and Sarawak was due to the introduction of Self-Assessment System (SAS), with tax knowledge and tax literacy become the most salient factor (e.g., 
Nero Madi, 1999; Junainah Jaidi, 2002; Amrizah Kamaluddin \& Nero Madi, 2005; Nero Madi et al., 2010; Khalizatul Asrin Mazlan, 2012; Junainah Jaidi et al., 2013). However, none of their studies attempt to provide empirical evidence of institutional factor that link governance quality to tax compliance. Besides, Sabah and Sarawak are historically different from its peers in peninsular Malaysia. For instance, East Malaysia do not involve in Malaysia's independence in 1957, nor did both states experience racial riots on $13^{\text {th }}$ May 1969. In the other hand, variances in the degree of tax compliance behaviour may due to different level of median household income which rank Sabah and Sarawak among the lowest within the 16 states or territories in Malaysia (Department of Statistics Malaysia, 2020a).

\section{SURVEY INSTRUMENTS}

The questionnaires were developed in English and amended to satisfy the needs of the research objectives covering the taxation environment in Malaysia. Variables were measured through respondents' perceptions of tax compliance, voice and accountability, political stability, government effectiveness, and the rule of law on a scale of 1 (strongly disagree) to 5 (strongly agree).

\section{TAX COMPLIANCE}

Generally, tax compliance indicates the action of declaring the correct tax information and paying the tax due within the prescribed time limit, in support to adherence of the relevant tax laws in their respective country of residence (Owusu et al. 2019; Youde \& Lim 2019). Specifically, Kirchler \& Wahl (2010) claimed that the willingness of the taxpayer to pay taxes indicates tax compliance, whereas non-compliance relates to the behavioural result of paying less tax than what is required. In the present study, the likelihood of taxpayers to comply or not comply with tax requirement is measured, or the extent to which individuals feel morally obliged to pay taxes, as adopted from Kirchler and Wahl (2010).

\section{GOVERNANCE}

Kaufmann et al. (2011) pointed out that although a range of cross-national governance indicators is available worldwide, the WGI (World Governance Indicator) of the World Bank is currently probably the most successful effort to operationalise the concept of good governance into executable policy tools. Following the same initiative, this study borrowed World Bank's governance measures, which cut across the four proxies of (1) voice and accountability, (2) political stability, (3) government effectiveness, and (4) the rule of law. The construct outlined by Kaufmann et al. (2011) appears to have captured a wide range of government activities. Thus, this construct is ideal for governance assessment. Different from previous studies, which use governance index as governance quality, the current research measured governance quality through taxpayers' perception on how good or how bad their government executes its duties to satisfy or dissatisfy its citizens. Table 1 briefly explains the four proxies of governance as presented by Kaufmann et al. (2011)

TABLE 1. Governance measures

\begin{tabular}{ll}
\hline \multicolumn{1}{c}{ Proxies } & \multicolumn{1}{c}{ Description } \\
\hline Voice and & $\begin{array}{l}\text { Reflect the perception of citizens' ability to select those that represent them in } \\
\text { government. It also assesses citizens' right to share their opinions on governance issues. It } \\
\text { serves to have access to important information for monitoring performance from which } \\
\text { public opinion can be heard. }\end{array}$ \\
\hline Political & $\begin{array}{l}\text { Illustrate the perception capturing the political strength of local governments, steadiness } \\
\text { of the policies and likelihood of political instability or political unrest. }\end{array}$ \\
\hline Stability & This proxy measures the quality expectations of public services and the credibility of \\
Effectiveness & $\begin{array}{l}\text { government commitment to civil services. It also assesses the quality of policy } \\
\text { formulation, quality of public goods delivery, and the ability of governments to enforce }\end{array}$ \\
\hline such policies.
\end{tabular}

Source: World Bank’s Governance Measures and Kaufmann et al. (2011)

\section{DATA ANALYSIS AND PROCEDURES}

In the initial pre-analysis stage, all collected data are first entered for data cleaning and screening using the IBM SPSS 25 , including the descriptive and inferential analyses. Outliers, skewness, and kurtosis are preliminarily checked, with the assumption that normal data distribution is established. SmartPLS 3.3.2 was used for assessing the overall fit of the 
measurement and structural models. The choice of PLS-SEM was based on a few reasons. At first sight, PLS does not require a minimum of restrictive assumptions, such as sample size, measurement scale or distributional assumption (Peng \& Lai 2012). In addition, the statistical significance that maximises the explained variance $\left(R^{2}\right)$ of the endogenous latent construct (dependent variables) can be explained through the strength and path coefficient in PLS (Hair et al. 2016). Nonetheless, PLS-SEM also makes great use of obtaining knowledge drivers to test the cause and effect relationship (Hair et al. 2018). Since the research objective in the study is related to theory development and explanation of variance, the adaptation of PLS-SEM is considered acceptable. Thus, the two suggested consecutive steps of the measurement model and structural model by Hair et al. (2016) will be explained in the next sections.

\section{RESULTS}

\section{SAMPLE CHARACTERISTIC}

Table 2 highlights the descriptive data of the respondents. A total of 41 (52.6\%) respondents are female, and 37 (47.4\%) are male. Fifty-two (66.7\%) respondents are married with age ranging 31-40 years old. In terms of educational background, $55(70.5 \%)$ respondents hold bachelor and master's degrees, followed by $5(6.4 \%)$ respondents with a diploma, and $4(5.1 \%)$ with a professional qualification. A total of $73(93.6 \%)$ respondents works for public and private sectors, whereas $5(6.4 \%)$ are self-employed.

TABLE 2. Descriptive summary of the sample

\begin{tabular}{ccc}
\hline \multicolumn{1}{c}{ Items } & Respondent $(N=78)$ & Percentage (\%) \\
\hline Gender & 37 & \\
$\quad$ Male & 41 & 47.4 \\
Age $\quad$ Female & & 52.6 \\
$\quad<30$ years old & 6 & 7.7 \\
31-40 years old & 52 & 66.7 \\
41-50 years old & 13 & 16.7 \\
51-60 years old & 7 & 9.0 \\
Marital Status & & 32.1 \\
Single & 25 & 66.7 \\
Married & 52 & 1.3 \\
Divorce & 1 & 6.4 \\
Highest Education Level & & 25.6 \\
Diploma & 5 & 5.1 \\
Bachelor's degree (e.g., BA, BS) & 20 & 44.9 \\
Professional (e.g., ACCA and CIMA) & 4 & 17.9 \\
Master's degree (e.g., MA and MS) & 35 & \\
Doctorate (e.g., PhD and EdD) & 14 & 6.4 \\
Current Occupational Status & & 70.5 \\
Self-employed & 5 & 23.1 \\
Public sector-employed & 55 & \\
Private sector-employed & 18 & \\
& &
\end{tabular}

Assessment of Measurement Model (Reliability and Validity)

To assess the measurement model in PLS-SEM, the variables in the survey questionnaires should be reliable. Four assessment criteria are needed in this outset, comprising internal consistency reliability, indicator reliability, convergent validity, and discriminant validity (Hair et al. 2016). Internal consistency reliability provides an estimate of reliability based on the intercorrelation of the observed items, whether the items measuring a construct are identical in their scores (Hair et al. 2016). The results in Table 3 show that internal consistency reliability is satisfactory, given that all Composite reliability (CR) values are larger than 0.70 (Hair et al. 2016).

Indicator reliability is evaluated to measure the extent to which an indicator or set of indicators is consistent with what it intends to measure (Urbach and Ahlemann 2010). The item loadings are also shown in Table 3 . All recommended loadings greater than 0.60 (Byrne 2010) and above 0.708 are retained in the study, whereas loadings below 0.40 are deleted (Hulland 1999; Hair et al. 2016). During the deletion process, all five constructs satisfy the threshold values for CR and Average Variance Extracted (AVE). All CR values are more than 0.70, and all AVE values are more than 0.5 after the item deletion process (Hair et al. 2016). 
TABLE 3. Indicator reliability, internal consistency, and convergent validity

\begin{tabular}{|c|c|c|c|c|c|}
\hline Construct & Item & $\begin{array}{c}\text { Item } \\
\text { Loading }\end{array}$ & $\begin{array}{l}\text { Cronbach } \\
\text { Alpha }\end{array}$ & $\begin{array}{c}\text { Composite } \\
\text { Reliability } \\
\text { (CR) }\end{array}$ & $\begin{array}{l}\text { Average Variance Extracted } \\
\qquad(\mathrm{AVE})>0.5\end{array}$ \\
\hline \multirow{2}{*}{$\begin{array}{l}\text { Voice and } \\
\text { Accountability }\end{array}$} & VA_1 & 0.960 & \multirow[t]{2}{*}{0.792} & \multirow[t]{2}{*}{0.897} & \multirow[t]{2}{*}{0.814} \\
\hline & VA_2 & 0.841 & & & \\
\hline \multirow{2}{*}{ Political Stability } & PS_1 & 0.882 & \multirow[t]{2}{*}{0.693} & \multirow[t]{2}{*}{0.867} & \multirow[t]{2}{*}{0.765} \\
\hline & PS_2 & 0.866 & & & \\
\hline \multirow{3}{*}{$\begin{array}{l}\text { Government } \\
\text { Effectiveness }\end{array}$} & GE_1 & 0.840 & \multirow{3}{*}{0.806} & \multirow{3}{*}{0.869} & \multirow{3}{*}{0.692} \\
\hline & GE_2 & 0.704 & & & \\
\hline & $\mathrm{GE}_{-}^{-} 3$ & 0.935 & & & \\
\hline \multirow{3}{*}{ Rule of Law } & RL_1 & 0.856 & \multirow{3}{*}{0.701} & \multirow{3}{*}{0.828} & \multirow{3}{*}{0.620} \\
\hline & $\mathrm{RL}_{-} 2$ & 0.850 & & & \\
\hline & $\mathrm{RL}_{-} 3$ & 0.636 & & & \\
\hline \multirow{7}{*}{ Tax Compliance } & TC_1 & 0.718 & \multirow{7}{*}{0.840} & \multirow{7}{*}{0.855} & \\
\hline & TC_3 & 0.702 & & & \\
\hline & $\mathrm{TC}_{-} 4$ & 0.733 & & & \\
\hline & $\mathrm{TC}_{-}^{-} 5$ & 0.589 & & & \\
\hline & $\mathrm{TC}_{-} 7$ & 0.814 & & & \\
\hline & $\mathrm{TC} \_8$ & 0.658 & & & \\
\hline & TC_10 & 0.783 & & & \\
\hline
\end{tabular}

Subsequently, convergent validity is assessed through the observation of AVE values. Convergent validity is the degree to which individual indicators positively correlate with other indicators of the same construct (Urbach and Ahlemann 2010). That is, a construct should account at least 50\% variances of its indicators for adequate convergent validity (Fornell \& Larcker 1981; Bagozzi \& Yi 1988; Hair et al. 2016). As shown in Table 3, all five constructs meet the convergent validity requirement with AVE values greater than 0.50 .

Discriminant validity is summarised in Table 4. Discriminant validity is used to ensure that one construct should be distinct and should load more strongly on its construct relative to other constructs. In PLS, cross-loadings, Fornell and Larcker criterion (Fornell and Larcker 1981), and Heterotrait-Monotrait (HTMT) criterion (Henseler et al. 2015) are available to assess discriminant validity. For cross-loadings, Table 4 reports high loadings (bolded values) on its constructs but low on the other constructs on all indicators (nonbolded values).

TABLE 4. Discriminant validity using Cross Loadings, Fornell-Lacker and HTMT

\begin{tabular}{cccccc}
\hline Item Constructs & GE & PS & RL & VA & TC \\
\hline Cross-loadings & & & & & 0.447 \\
GE_1 & $\mathbf{0 . 8 4 0}$ & 0.570 & 0.348 & 0.447 & 0.060 \\
GE_2 & $\mathbf{0 . 7 0 4}$ & 0.361 & 0.352 & 0.367 & 0.272 \\
GE_3 & $\mathbf{0 . 9 3 5}$ & 0.458 & 0.438 & 0.410 & 0.320 \\
PS_1 & 0.530 & $\mathbf{0 . 8 8 2}$ & 0.339 & 0.378 & 0.301 \\
PS_2 & 0.432 & $\mathbf{0 . 8 6 6}$ & 0.415 & 0.485 & 0.366 \\
RL_1 & 0.518 & 0.418 & $\mathbf{0 . 8 5 6}$ & 0.421 & 0.334 \\
RL_2 & 0.313 & 0.280 & $\mathbf{0 . 8 5 0}$ & 0.242 & 0.180 \\
RL_3 & 0.164 & 0.328 & $\mathbf{0 . 6 3 6}$ & $\mathbf{0 . 9 6 0}$ & 0.358 \\
VA_1 & 0.445 & 0.425 & 0.500 & $\mathbf{0 . 8 4 1}$ & 0.186 \\
VA_2 & 0.381 & 0.394 & 0.402 & 0.242 & $\mathbf{0 . 7 1 8}$ \\
TC_1 & 0.180 & 0.308 & 0.197 & 0.249 & $\mathbf{0 . 7 0 2}$ \\
TC_3 & 0.148 & 0.161 & 0.271 & 0.224 & $\mathbf{0 . 7 3 3}$ \\
TC_4 & 0.190 & 0.308 & 0.229 & 0.157 & $\mathbf{0 . 5 8 9}$ \\
TC_5 & 0.155 & 0.287 & 0.233 & 0.238 & $\mathbf{0 . 8 1 4}$ \\
TC_7 & 0.299 & 0.285 & 0.446 & 0.151 & $\mathbf{0 . 6 5 8}$ \\
TC_8 & 0.013 & 0.170 & 0.242 & 0.350 & $\mathbf{0 . 7 8 3}$ \\
TC_10 & 0.156 & 0.246 & 0.286 & & \\
\hline Fornell-Lacker Method Discriminant Validity & & & \\
GE & $\mathbf{0 . 8 3 2}$ & & & & \\
PS & 0.552 & $\mathbf{0 . 8 7 4}$ & 0.429 & & \\
RL & 0.454 & & & & \\
\hline
\end{tabular}




\begin{tabular}{|c|c|c|c|c|c|}
\hline VA & 0.460 & 0.451 & 0.508 & 0.902 & \\
\hline TC & 0.240 & 0.355 & 0.390 & 0.326 & 0.717 \\
\hline \multicolumn{6}{|c|}{ Heterotrait-Monotrait (HTMT) Method Discriminant Validity } \\
\hline \multirow[t]{3}{*}{ PS } & 0.727 & & & & \\
\hline & CI.90 & & & & \\
\hline & $(0.498,0.874)$ & & & & \\
\hline \multirow[t]{3}{*}{ RL } & 0.537 & 0.624 & & & \\
\hline & CI.90 & CI.90 & & & \\
\hline & $(0.290,0.727)$ & $(0.361,0.868)$ & & & \\
\hline \multirow[t]{3}{*}{ VA } & 0.613 & 0.607 & 0.636 & & \\
\hline & CI.90 & CI.90 & CI.90 & & \\
\hline & $(0.276,0.812)$ & $(0.358,0.788)$ & $(0.401,0.835)$ & & \\
\hline \multirow[t]{3}{*}{$\mathrm{TC}$} & 0.239 & 0.462 & 0.470 & 0.364 & \\
\hline & CI.90 & CI.90 & CI.90 & CI.90 & \\
\hline & $(0.151,0.293)$ & $(0.269,0.637)$ & $(0.264,0.643)$ & $(0.172,0.522)$ & \\
\hline
\end{tabular}

Note: GE: Government Effectiveness; PS: Political Stability; RL: Rule of Law; VA: Voice and Accountability; TC: Tax Compliance. A threshold of HTMT.85 (Kline 2011) and HTMT.90 (Gold et al. 2001).

Besides, the Fornell-Lacker criterion revealed that all square roots of AVE (bolded values) are greater than the intercorrelations (nonbolded values) in their corresponding rows and columns. Given the limitation of the classic FornellLarcker test and cross-loading in detecting the problems of discriminant validity, this study uses the third method of HTMT by Henseler et al. (2015). As shown in Table 4, all HTMT values are less than the maximum threshold value of HTMT $_{.85}$ (Kline 2011) and HTMT. ${ }_{.90}$ (Gold et al. 2001). This finding posits that discriminant validity has been ascertained. Furthermore, the confidence interval (CI) on the HTMT result shows the non-existent value of 1 on any construct, thus establishing discriminant validity. Hence, all results of cross-loading, Fornell-Lacker and HTMT values confirm the satisfactory of discriminant validity in the measurement model.

\section{COLLINEARITY ASSESSMENT}

In the initial stage of assessing the structural model, issues of lateral collinearity should be firstly addressed. Despite that discriminant validity has been fulfilled in the beginning, lateral collinearity may sometimes mislead the results in a stealth approach, that is, it can mask the strong causal effect in the model (Kock \& Lynn 2012). All the inner Variance Inflation Factor (VIF) values of other independent variables (voice and accountability VIF $=1.538$, political stability vIF $=1.586$, government effectiveness $\mathrm{VIF}=1.630$, and the rule of law $\mathrm{VIF}=1.507)$ are less than 5 . This result indicates that lateral multicollinearity is not a problem in the study (Hair et al. 2016).

\section{ASSESSMENT OF STRUCTURAL MODEL (HYPOTHESIS TESTING)}

Once the assessment in the measurement model has been established, the assessment of the structural model is required. In this model, the hypothesised relationship between exogenous and endogenous variables can, therefore be confirmed whether or not the extracted hypothesis can be supported and validated by the structural model (Urbach and Ahlemann 2010). Table 5 presents the outcome of hypothesis testing. The $R^{2}$ value indicates that $20.5 \%$ variance in tax compliance is predicted by all the four constructs. The outcome of $R^{2}$ value larger than 0.13 implies a moderate model in the study (Cohen 1988). For the recommendation of Falk and Miller (1992), $R^{2}$ values equal to or exceeding 0.10 should be considered sufficient to explain the variance of certain endogenous constructs adequately. Four direct hypotheses are formulated among the constructs. To test the significant level, the $t$-statistics for all paths are generated using the bootstrap function in Smart PLS. Our hypotheses were tested using bootstrapping procedures of 78 observations on 5,000 bootstrapped resamples.

TABLE 5. Effects on endogenous variable (hypothesis testing)

\begin{tabular}{|c|c|c|c|c|c|c|c|c|}
\hline $\begin{array}{c}\text { Hypothesis: Path } \\
\text { Model }\end{array}$ & $\beta$ & $S E$ & $t$-value & $\begin{array}{c}90 \% \\
\text { Boot CI }\end{array}$ & $R^{2}$ & $f^{2}$ & $Q^{2}$ & Decision \\
\hline H1: VA $\rightarrow$ TC & 0.120 & 0.167 & 0.715 & $-0.116,0.299$ & & 0.012 & & Rejected \\
\hline $\mathrm{H} 2: \mathrm{PS} \rightarrow \mathrm{TC}$ & 0.220 & 0.134 & $1.634 *$ & $0.059,0.389$ & 0.205 & 0.038 & 0.073 & Supported \\
\hline H3: $\mathrm{GE} \rightarrow>\mathrm{TC}$ & -0.054 & 0.192 & 0.282 & $-0.387,0.124$ & & 0.002 & & Rejected \\
\hline H4: RL $\rightarrow$ TC & 0.260 & 0.140 & $1.853 * *$ & $0.085,0.446$ & & 0.056 & & Supported \\
\hline
\end{tabular}

Note: If $* p<0.10$, if $* * p<0.05$; for $f^{2}$ and $Q^{2}, 0.02$ small effects, 0.15 medium effects, 0.35 substantial effects GE: Government Effectiveness; PS: Political Stability; RL: Rule of Law; VA: Voice and Accountability; TC: Tax Compliance. 
Among all paths, only two paths are found to be significant at 0.05 and 0.10 significance levels. Specifically, the predictor of political stability (PS) $(\beta=0.220, t=1.634, p<0.10)$ and rule of law (RL) $(\beta=0.260, t=1.853, p<0.05)$ are positively related to tax compliance. In addition, the CI bias results of political stability (Boot CI: $\mathrm{LL}=0.059, \mathrm{UL}=0.389$ ) and rule of law (Boot CI: $\mathrm{LL}=0.085, \mathrm{UL}=0.446$ ) do not straddle at zero, also indicating significant results. Thus, $\mathrm{H}_{2}$ and $\mathrm{H}_{4}$ are supported. With regards to proxies of voices and accountability and government effectiveness, the $p>0.10$ and also the Boot CI straddle at zero for both $\mathrm{H}_{1}$ (Boot $\mathrm{CI}$ : $\mathrm{LL}=-0.116$, $\mathrm{UL}=0.299$ ) and $\mathrm{H}_{3}$ (Boot $\left.\mathrm{CI}: \mathrm{LL}=-0.387, \mathrm{UL}=0.124\right)$, thus allowing the study to strongly reject $\mathrm{H} 1$ and $\mathrm{H} 3$.

According to Hair et al. (2016), the outcome of effect size $\left(f^{2}\right)$ and predictive relevance $\left(Q^{2}\right)$ in PLS should also be reported in PLS (Ramayah et al. 2018). Sullivan and Feinn (2012, p. 279) conjectured that "While a p-value can inform the reader whether an effect exists, the p-value will not reveal the size of the effect. In reporting and interpreting studies, both the substantive significance (effect size) and statistical significance ( -value) are essential results to be reported." To measure the effect size, the rule of thumb by Cohen (1988) is used, that is, the values of $0.02,0.15$, and 0.35 represent small, medium, and large effects, respectively. Table 4 shows that all constructs have small effects on producing the $R^{2}$ for tax compliance, except for government effectiveness with no effect on tax compliance.

This study adopts the Stones-Geisser approach in assessing the predictive relevance of a research model by using the blindfolding procedure (Geisser 1974; Stone 1974). According to Duarte \& Raposo (2010), the Stone-Geisser test for predictive relevance is widely used as a complement to the goodness-of-fit in PLS. The $Q^{2}$ value of 0.073 in Table 5 is greater than zero, indicating that the exogenous construct of a model has a small degree of predictive relevance over the endogenous construct of tax compliance (Cohen 1988; Hair et al. 2016).

\section{DISCUSSION}

Several observations can be drawn from this study. We only find half-strong evidence that taxpayer's perception of the quality of government is associated with increased tax compliance. Although voice and accountability and government effectiveness are an essential factor in understanding governance quality, it has no direct impact on compliance with tax. In particular, the significant increase of taxpayer's obedience is only through their perception of political stability and the rule of law.

Our findings (H2) are consistent with those of Damania et al. (2004) and Aizenman and Jinjarak (2008). However, our finding contradicts that of Tedds (2010) who argued political instability as having no effect on tax underreporting but claiming that political unrest could limit a country's ability to collect taxes. Arguing that political stability strengthens institutional structures, which in turn create an environment of gaining further support from taxpayers, is reasonable. Radu (2015) suggested that a stable political environment helps create a cohesive and continuing path toward the sustainable economic growth of a country. Lately in Malaysia, political unrest with changes of national administration just within few years may adversely affect taxpayer's compliance.

The rule of law $\left(\mathrm{H}_{4}\right)$ construct is in line with Torgler and Schneider (2009), who established that an effective and the efficient rule of law could be positively perceived by its people to ensure adequate sanction for any offences or non-compliance. In this context, the United Nations Development Programme (2013: 10) stated that "strengthening the rule of law is at the heart of the social contract" because the absence or ineffectiveness of the rule of law can significantly diminish country or state performance. Nevertheless, Bergman (2009) and Mohammed Abdullahi Umar et al. (2019) also supported the notion that readiness to pay tax is high if the rule of law is practically well established.

The insignificant results of $\left(\mathrm{H}_{1}\right)$ and $\left(\mathrm{H}_{3}\right)$ indicate that the Sabahan and Sarawakian taxpayers do not consider the constructs of voice and accountability and government effectiveness as generally crucial in determining their compliance with the assumption that the government should be inherently accountable to its citizens, given the power entrusted to the them. In short, the ideology on how respective government administer the country and state may contribute different perceptions on governance quality.

\section{THEORETICAL AND PRACTICAL IMPLICATIONS}

From the theoretical points of view, our key contribution lies in identifying the role of governance within the structure of tax compliance. To date, taxpayers' perception of governance in East Malaysia is non-existent in the tax literature, thus open possibilities for alternative justification. The present study, therefore, is the first attempt to fill up the research gap. The significant results conclude that although all governance quality constructs are essential to creating compliance, a stable political environment and the effective rule of law are found to influence tax compliance behavior among taxpayers in Sabah and Sarawak.

Expanding to continue supporting the previous work of Damania et al. (2004) and Aizenman and Jinjarak (2008), the analysis affirms our prediction that political instability may adversely affect compliance. As taxpayers lose confidence in the system, the consequences from political instability will only lead to the adverse outcome on economic growth as it also led to the issue of tax compliance. Thus, the study suggests that political parties in Malaysia, whether 
from coalition or opposition, should come into a mutual agreed commitment in maintaining a positive and vibrant political interest for the benefit of all citizens. Otherwise, the atmosphere of the country or state may experience sudden changes or failures. Therefore, it is advisable that the right and freedom of people should be respected, the corruption and mismanagement of the wealth of a country must be avoided, and the openness and transparency of a government should be supported to ensure a stable political environment. From the lens of taxation, this condition can be translated, as given that political stability is necessary if governments wish to demand taxpayers to contribute in the form of tax payment; otherwise, disruption in the political system is retaliated with violence, protest, and finally non- tax compliance.

The findings also revealed effective rule of law had significant positive influences on tax compliance, which corroborated with other studies (Torgler and Schneider 2009; Bergman 2009) and latest work of Mohammed Abdullahi Umar et al. (2019). Hence, this governance quality should not be overlooked. The plausible reason is that it allows taxpayers to predict the consequences of their and others' actions of not complying with tax laws. It is suggested that the government should properly interpret the existing tax law to ensure continual tax collection among the governed population, and such collection is the key component of a tax system. For the law to be effectively implemented, proposing stricter rules is recommended as compassion to reshape the attitude of the citizen to be more compliant.

However, it was necessary to note that strict rules must not be exercised in isolation; it has to be accompanied by the legitimacy that can win the heart and trust of their taxpayers. The reason is strict rules may be retaliated with unpleasant behaviour such as protest and violence, which in turn leads to non-compliance. One approach that can be undertaken is for governments to blend the concept of justice and security that addresses the issues of violence, conflict, and crimes. Another approach is to promote a rule of law that is responsive to the demand of taxpayers; a method that may strengthen democratic governance.

\section{CONCLUSION}

This study examines whether and how governance quality affects tax compliance in East Malaysia. The relationship between governance quality and tax compliance is identified using the PLS-SEM with bootstrapping. Contrary to previous studies, which use the index as measurement for governance quality on tax compliance, the present study uses an approach of obtaining taxpayers' perception of governance practices in Malaysia by using survey questionnaire. Legitimacy theory is also applied on the basis of empirical evidence.

Like other studies, the present research is subject to limitations. The data used in this study primarily focus on individual taxpayers, but the perception, opinion, and behaviour toward governance quality may not be similar to those of corporate taxpayers. Furthermore, the low response rate can limit the research findings in generalising results that represent taxpayers' population at large in East Malaysia. Since this study still at its initial stage, the preliminary analysis with the low response rate may reject few hypotheses. Despite of these limitations, this research has made few contributions. First it provides empirical validation on the effect of governance quality on tax compliance when political stability was found to be positive and had a significant link with tax compliance, in collaboration with Damania et al. (2004) and Aizenman and Jinjarak (2008). Secondly, effective rule of law is significantly found to increase tax compliance, consistent with that of other research studies (Torgler \& Schneider 2009; Bergman 2009; Mohammed Abdullahi Umar et al. 2019).

Expanding on the model proposed in this research, future research should consider the phycological behaviour of tax morale. Prior studies have overlooked the mediating effect of tax morality, in particular its function as a mechanism between governance and tax compliance. The rationalisation to include morale for tax compliance is based on the argument of the norms model (Doran 2009) and morale cost that can be a significant mechanism for changing human behaviour (Levitt \& List 2007). Future research can also include individual taxpayers from other states in Malaysia for conclusive findings.

Finally, research on the direct effect of government effectiveness, and voice and accountability on tax compliance will lead to uncovered potential discoveries, given the empirical results have shown negative and positive relationship respectively, but insignificant. In a nutshell and as a starting point, we have introduced a framework of governance-tax compliance model which is useful for other potential study.

\section{REFERENCES}

Aizenman, J. \& Jinjarak, Y. 2008. The Collection Efficiency of the Value Added Tax: Theory and International Evidence. Journal of International Trade and Economic Development 17(3): 391-410.

Allingham, M.G. \& Sandmo, A. 1972. Income Tax Evasion: A Theoretical Analysis. Journal of Public Economics 1(3-4): 323-338.

Alm, J. \& Luis Gomez, J. 2008. Social Capital and Tax Morale in Spain. Economic Analysis and Policy 38(1): $73-87$.

Amrizah Kamaluddin \& Nero Madi. 2005. Tax Literacy and Tax Awareness of Salaried Individuals in Sabah and Sarawak. National Accounting Research Journal 3(1): 71-89. 
Association of International Certified Professional Accountants (AICPA). 2017. Guiding Principles of Good Tax Policy: A Framework for Evaluating Tax Proposals.

Bagozzi, R. \& Yi, Y. 1988. On the Evaluation of Structure Equation Models. Journal of the Academy of Marketing Science 16(1): 74-04.

Batrancea, L., Nichita, A., Olsen, J., Kogler, C., Kirchler, E., Hoelzl, E., Weiss, A., Torgler, B., Fooken, J., Fuller, J., Schaffner, M., Banuri, S., Hassanein, M., Alarcón-García, G., Aldemir, C., Apostol, O., Bank Weinberg, D., Batrancea, I., Belianin, A., Bello Gómez, F. de J., Briguglio, M., Dermol, V., Doyle, E., Gcabo, R., Gong, B., Ennya, S., Essel-Anderson, A., Frecknall-Hughes, J., Hasanain, A., Hizen, Y., Huber, O., Kaplanoglou, G., Kudła, J., Lemoine, J.E., Leurcharusmee, S., Matthiasson, T., Mehta, S., Min, S., Naufal, G., Niskanen, M., Nordblom, K., Öztürk, E.B., Pacheco, L., Pántya, J., Rapanos, V., Roland-Lévy, C., Roux-Cesar, A.M., Salamzadeh, A., Savadori, L., Schei, V., Sharma, M., Summers, B., Suriya, K., Tran, Q., Villegas-Palacio, C., Visser, M., Xia, C., Yi, S. \& Zukauskas, S. 2019. Trust and Power as Determinants of Tax Compliance Across 44 Nations. Journal of Economic Psychology 74102191.

Benk, S., Budak, T., Püren, S. \& Erdem, M. 2015. Perception of Tax Evasion as a Crime in Turkey. Journal of Money Laundering Control 18(1): 99-111.

Bergman, M. 2009. Tax Evasion and The Rule of Law in Latin America: The Political Culture of Cheating and Compliance in Argentina and Chile. Pennsylvania: The Pennsylvania University Press.

Besançon, M. 2003. Good Governance Rankings: The Art of Measurement. World Peace Foundation Cambridge: World Peace Foundation.

Byrne, B.M. 2010. Structural Equation Modeling with AMOS: Basic Concepts, Applications, and Programming. 2nd Ed.,. New York: Routledge.

Casal, S., Kogler, C., Mittone, L. \& Kirchler, E. 2016. Tax Compliance Depends on Voice of Taxpayers. Journal of Economic Psychology journal 56 141-150.

Chong, K.R. \& Arunachalam, M. 2018. Determinants of Enforced Tax Compliance: Empirical Evidence from Malaysia. Advances in Taxation 25 147-172.

Cohen, J. 1988. Statistical Power Analysis for the Behavioral Sciences. 2nd Ed.,. New Jersey: Lawrence Erlbaum Associates.

Cummings, R.G., Martinez-Vazquez, J., McKeec, M. \& Torgler, B. 2009. Tax Morale Affects Tax Compliance: Evidence from Surveys and an Artefactual Field Experiment. Journal of Economic Behavior \& Organization 70 447-457.

Da Cruz, N.F. \& Marques, R.C. 2017. Structuring Composite Local Governance Indicators. Policy Studies 38(2): 109129.

Damania, R., Fredriksson, P.G. \& Mani, M. 2004. The Persistence of Corruption and Regulatory Compliance Failures: Theory and Evidence. Public Choice $121363-390$.

Department of Statistics Malaysia. 2020. Report of Household Income and Basic Amenities Survey of 2019. Putrajaya.

Devos, K. 2012. A Comparative Study of Compliant and Non-Compliant Individual Taxpayers in Australia. Journal of Business and Policy Research 7(2): 180-196.

Doran, M. 2009. Tax Penalties and Tax Compliance. Harvard Journal on Legislation 46(1): 111-161.

Duarte, P.A.O. \& Raposo, L.B. 2010. A PLS Model to Study Brand Preference: An Application to the Mobile Phone Market. In Vinzi, V.E., Chin, W.W., Henseler, J. \& Wang, H. (ed.). Handbook of Partial Least Squares, pp. 449-485. London: Springer.

Evans, J.R. \& Mathur, A. 2005. The Value of Online Surveys. Internet Research 15(2): 195-219.

Evans, J.R. \& Mathur, A. 2018. The Value of Online Surveys: A Look Back and A Look Ahead. Internet Research 28(4): 854-887.

Everest-Phillip, M. \& Sandall, R. 2009. Linking Business Tax Reform with Governance: How to Measure Success. Investment Climate in Practice Vol. 2. Washington DC: World Bank.

Falk, R.F. \& Miller, N.B. 1992. A Primer for Soft Modeling. Ohio: University of Akron Press.

Farrar, J., Hausserman, C. \& Pinto, O. 2020. Trust and Compliance Effects of Taxpayer Identity Theft: A Moderated Mediation Analysis. Journal of the American Taxation Association 42(1): 57-77.

Fjeldstad, O.H., Schulz-Herzenberg, C. \& Sjursen, I.H. 2012. Peoples' Views of Taxation in Africa: A Review of Research on Determinants of Tax Compliance. October Norway: Chr. Michelsen Institute (CMI).

Fornell, C. \& Larcker, D.F. 1981. Structural Equation Models with Unobservable Variables and Measurement Error: Algebra and Statistics. Journal of Marketing Research 18(3): 382-388.

Forteza, A. \& Noboa, C. 2019. Perceptions of Institutional Quality and Justification of Tax Evasion. Constitutional Political Economy 30 367-382.

Gangl, K., Hofmann, E. \& Kirchler, E. 2015. Tax Authorities’ Interaction with Taxpayers: A Conception of Compliance in Social Dilemmas by Power and Trust. New Ideas in Psychology 37 13-23.

Gangl, K., Muehlbacher, S., Groot, M. de, Goslinga, S., Hofmann, E., Kogler, C., Antonides, G. \& Kirchler, E. 2013. "How Can I Help You?" Perceived Service Orientation of Tax Authorities and Tax Compliance. FinanzArchiv (Public Finance Analysis) 69(4): 487-510.

Geisser, S. 1974. A Predictive Approach to the Random Effect Model. Biometrika 61(1): 101-107. 
Gobena, L.B. \& Van Dijke, M. 2016. Power, Justice, and Trust: A Moderated Mediation Analysis of Tax Compliance among Ethiopian Business Owners. Journal of Economic Psychology 52 24-37.

Gold, A.H., Malhotra, A. \& Segars, A.H. 2001. Knowledge Management: An Organizational Capabilities Perspective. Journal of Management Information Systems 18(1): 185-214.

Hair, J.F., Babin, B.J., Anderson, R.E. \& Black, W.C. 2018. Multivariate Data Analysis. 8th Ed.,. London: Cengage.

Hair, J.F., Hult, G.T., Ringle, C. \& Sarstedt, M. 2016. A Primer on Partial Least Squares Structural Equation Modelling (PLS-SEM). 2nd Ed.,. Thousand Oaks: Sage.

Hallsworth, M., List, J.A., Metcalfe, R.D. \& Vlaev, I. 2017. The Behavioralist as Tax Collector: Using Natural Field Experiments to Enhance Tax Compliance. Journal of Public Economics 148 14-31.

Henseler, J., Ringle, C.M. \& Sarstedt, M. 2015. A New Criterion for Assessing Discriminant Validity in Variance-based Structural Equation Modeling. Journal of the Academy of Marketing Science 43(1): 115-135.

Hulland, J. 1999. Use of Partial Least Squares (PLS) in Strategic Management Research: A Review of Four Recent Studies. Strategic Management Journal 20 195-204.

Jimenez, P. \& Iyer, G.S. 2016. Tax Compliance in a Social Setting: The Influence of Social Norms, Trust in Government, and Perceived Fairness on Taxpayer Compliance. Advances in Accounting 34 17-26.

Junainah Jaidi. 2002. Sistem Taksiran Sendiri: Satu Kajian Kes Tanggapan Pembayar Cukai Individu di Kota Kinabalu (Self-Assessment System: A Case Study of Individual Taxpayer Perception in Kota Kinabalu). Master Dissertation, Universiti Kebangsaan Malaysia

Junainah Jaidi, Raman Noordin \& Abdul Wahid Mohd. Kassim. 2013. Individual Taxpayers' Perception Towards SelfAssessment System: A Case of Sabah. Journal of the Asian Academy of Applied Business 2 56-65.

Karlinsky, S., Burton, H. \& Blanthorne, C. 2004. Perceptions of Tax Evasion as a Crime. eJournal of Tax Research 2(2): $226-240$.

Kastlunger, B., Lozza, E., Kirchler, E. \& Schabmann, A. 2013. Powerful Authorities and Trusting Citizens: The Slippery Slope Framework and Tax Compliance in Italy. Journal of Economic Psychology 34 36-45.

Kaufmann, D., Kraay, A. \& Mastruzzi, M. 2011. The Worldwide Governance Indicators: Methodology and Analytical Issues. Hague Journal on the Rule of Law 3(2): 220-246.

Khalizatul Asrin Mazlan. 2012. A Study on Tax Knowledge and Tax Compliance in Self Assessment System Among Academicians in Kota Kinabalu, Sabah.Master Dissertation, Universiti Malaysia Sabah.

Kirchler, E. \& Wahl, I. 2010. Tax Compliance Inventory TAX-I: Designing an Inventory for Surveys of Tax Compliance. Journal of Economic Psychology 31(3): 331-346.

Kline, R.B. 2011. Principles and Practice of Structural Equation Modeling. 3rd Ed.,. New York: Guilford Press.

Kock, N. \& Lynn, G.S. 2012. Lateral Collinearity and Misleading Results in Variance-Based SEM: An Illustration and Recommendations. Journal of the Association for Information Systems 13(7): 546-580.

Lassen, D.D. 2007. Ethnic Divisions, Trust and the Size of the Informal Sector. Journal of Economic Behavior and Organization 63(3): 423-438.

Levi, M. 1989. Of Rule and Revenue. Berkeley: University of California Press.

Levitt, S.D. \& List, J.A. 2007. What Do Laboratory Experiments Measuring Social Preferences Reveal About the Real World? Journal of Economic Perspectives 21(2): 153-174.

Loomis, D.K. \& Paterson, S. 2018. A Comparison of Data Collection Methods: Mail Versus Online Surveys. Journal of Leisure Research 49(2): 133-149.

Modugu, K.P., Emmanuel \& Izedonmi, F. 2012. Government Accountability and Voluntary Tax Compliance in Nigeria. Research Journal of Finance and Accounting 3(5): 69-77.

Mohammed Abdullahi Umar, Chek Derashid, Idawati Ibrahim \& Zainol Bidin. 2019. Public Governance Quality and Tax Compliance Behavior in Developing Countries: The Mediating Role of Socioeconomic Conditions. International Journal of Social Economics 46(3): 338-351.

Nero Madi. 1999. Tax Literacy Among Sole Proprietors and Partners at Tabuan Jaya and King Centre Kuching, SarawakMaster Dissertation, Curtin University of Technology.

Nero Madi, Amrizah Kamaluddin, Tamoi Janggu, Muliati Binti Aba Ibrahim, Aizimah Binti Abu Samah \& Jusoff, K. 2010. Tax Literacy Among Employees: Sabah and Sarawak's Perspective. International Journal of Economics and Finance 2(1): 218-223.

Nkundabanyanga, S.K., Mvura, P., Nyamuyonjo, D., Opiso, J. \& Nakabuye, Z. 2017. Tax Compliance in A Developing Country: Understanding Taxpayers' Compliance Decision by Their Perceptions. Journal of Economic Studies 44(6): 931-957.

Organisation for Economic Co-operation and Development (OECD). 2004. Compliance Risk Management: Managing and Improving Tax Compliance. Centre for Tax Policy and Administration Paris.

Organisation for Economic Co-operation and Development (OECD). 2010. Understanding and Influencing Taxpayers' Compliance Behaviour. Forum on Tax Administration: Small/Medium Enterprise Compliance Subgroup Centre for Tax Policy and Administration (CTPA).

Ortega, D., Ronconi, L. \& Sanguinetti, P. 2016. Reciprocity and Willingness to Pay Taxes: Evidence From a Survey Experiment in Latin America. Economía 16(2): 55-87. 
Owusu, G.M.Y., Bekoe, R.A., Otchere, O.A.S. \& Effah, N.A.A. 2019. Determinants of Tax Compliance Attitude. In Farazmand, A. (ed.). Global Encyclopedia of Public Administration, Public Policy, and Governance, Reprint. pp. 1-8. Cham: Springer.

Peng, D.X. \& Lai, F. 2012. Using Partial Least Squares in Operations Management Research: A Practical Guideline and Summary of Past Research. Journal of Operations Management 30(6): 467-480.

Picur, R.D. \& Riahi-Belkaoui, A. 2006. The Impact of Bureaucracy, Corruption and Tax Compliance. Review of Accounting and Finance 5(2): 174-180.

Radu, M. 2015. Political Stability - A Condition for Sustainable Growth in Romania? Procedia Economics and Finance 30 751-757.

Ramayah, T., Cheah, J., Chuah, F., Ting, H. \& Memon, M.A. 2018. Partial Least Squares Structural Equation Modelling (PLS-SEM) Using SmartPLS 3.0: An Updated Guide and Practical Guide to Statistical Analysis. 2nd Ed.,. Kuala Lumpur: Pearson.

Riahi-Belkaoui, A. 2004. Relationship between Tax Compliance Internationally and Selected Determinants of Tax Morale. Journal of International Accounting, Auditing and Taxation 13(2): 135-143.

Rodriguez-Justicia, D. \& Theilen, B. 2018. Education and Tax Morale. Journal of Economic Psychology 64 18-48.

Sen, K. 2014. Governance and Development Outcomes in Asia. ADB Economics Working Paper Series No. 384 January Manila: Asian Development Bank (ADB).

Slemrod, J. 2003. Trust in Public Finance. In Cnossen, S. \& Sinn, H.-W. (ed.). Public Finance and Public Policy in the New Century, London: MIT Press.

Slemrod, J. 2019. Tax Compliance and Enforcement. Journal of Economic Literature 57(4): 904-954.

Stone, M. 1974. Cross-Validatory Choice and Assessment of Statistical Predictions. Journal of the Royal Statistical Society: Series B (Methodological) 36(2): 111-133.

Sullivan, G.M. \& Feinn, R. 2012. Using Effect Size - or Why the P Value Is Not Enough. Journal of Graduate Medical Education 4(3): 279-282.

Tedds, L.M. 2010. Keeping It Off the Books: An Empirical Investigation of Firms that Engage in Tax Evasion. Applied Economics 42(19): 2459-2473.

The Edge. 2018. The State of the Nation: Considerations in Reforming Malaysia's Tax System. Retrieved 5 March 2020 from https://www.theedgemarkets.com/article/state-nation-considerations-reforming-malaysias-tax-system.

The Star. 2018. The Taxman Cometh for Defaulters. Retrieved 23 October 2019 from https:/www.thestar.com.my/news/nation/2018/11/14/the-taxman-cometh-for-defaulters-voluntarily-discloseyour-wealth-honestly-or-face-the-wrath-of-the .

Torgler, B. 2003. Tax Morale: Theory and Empirical Analysis of Tax Compliance. Ph.D. Thesis, University of Basel

Torgler, B. 2004. Tax Morale in Asian Countries. Journal of Asian Economics 15 237-266.

Torgler, B. 2007. Tax Compliance and Tax Morale: A Theoretical and Empirical Analysis. Cheltenham: Edward Elgar.

Torgler, B., Schaffner, M. \& Macintyre, A. 2007. Tax Compliance, Tax Morale, and Governance Quality. Working Paper No. 07-27 December Atlanta: Andrew Young School of Policy Studies, Georgia State University.

Torgler, B. \& Schneider, F. 2009. The Impact of Ttax Morale and Institutional Quality on the Shadow Economy. Journal of Economic Psychology 30(2): 228-245.

United Nations Development Programme (UNDP). 2013. Strengthening the Rule of Law in Crisis-Affected and Fragile Situations. Global Programme Annual Report 2011

Urbach, N. \& Ahlemann, F. 2010. Structural Equation Modeling in Information Systems Research Using Partial Least Squares. Journal of Information Technology Theory and Application 11(2): 5-40.

Wang, Z. 2010. Citizens' Satisfaction with Government Performance in Six Asian-Pacific Giants. Japanese Journal of Political Science 11(1): 51-75.

Youde, S. \& Lim, S. 2019. Tax Compliance. In Farazmand, A. (ed.). Global Encyclopedia of Public Administration, Public Policy, and Governance, Reprint. pp. 1-5. Cham: Springer.

Mohd Allif Anwar Abu Bakar*

Faculty of Economics and Management

Universiti Kebangsaan Malaysia

43600 UKM Bangi, Selangor

MALAYSIA

Faculty of Business, Economics and Accountancy

Universiti Malaysia Sabah

88400 Kota Kinabalu, Sabah

MALAYSIA

E-mail: p100330@siswa.ukm.edu.my 
Mohd Rizal Palil

Faculty of Economics and Management Universiti Kebangsaan Malaysia 43600 UKM Bangi, Selangor

MALAYSIA

E-mail: mr_palil@ukm.edu.my

Ruhanita Maelah

Faculty of Economics and Management Universiti Kebangsaan Malaysia

43600 UKM Bangi, Selangor

MALAYSIA

E-mail: ruhanita@ukm.edu.my

* Corresponding author

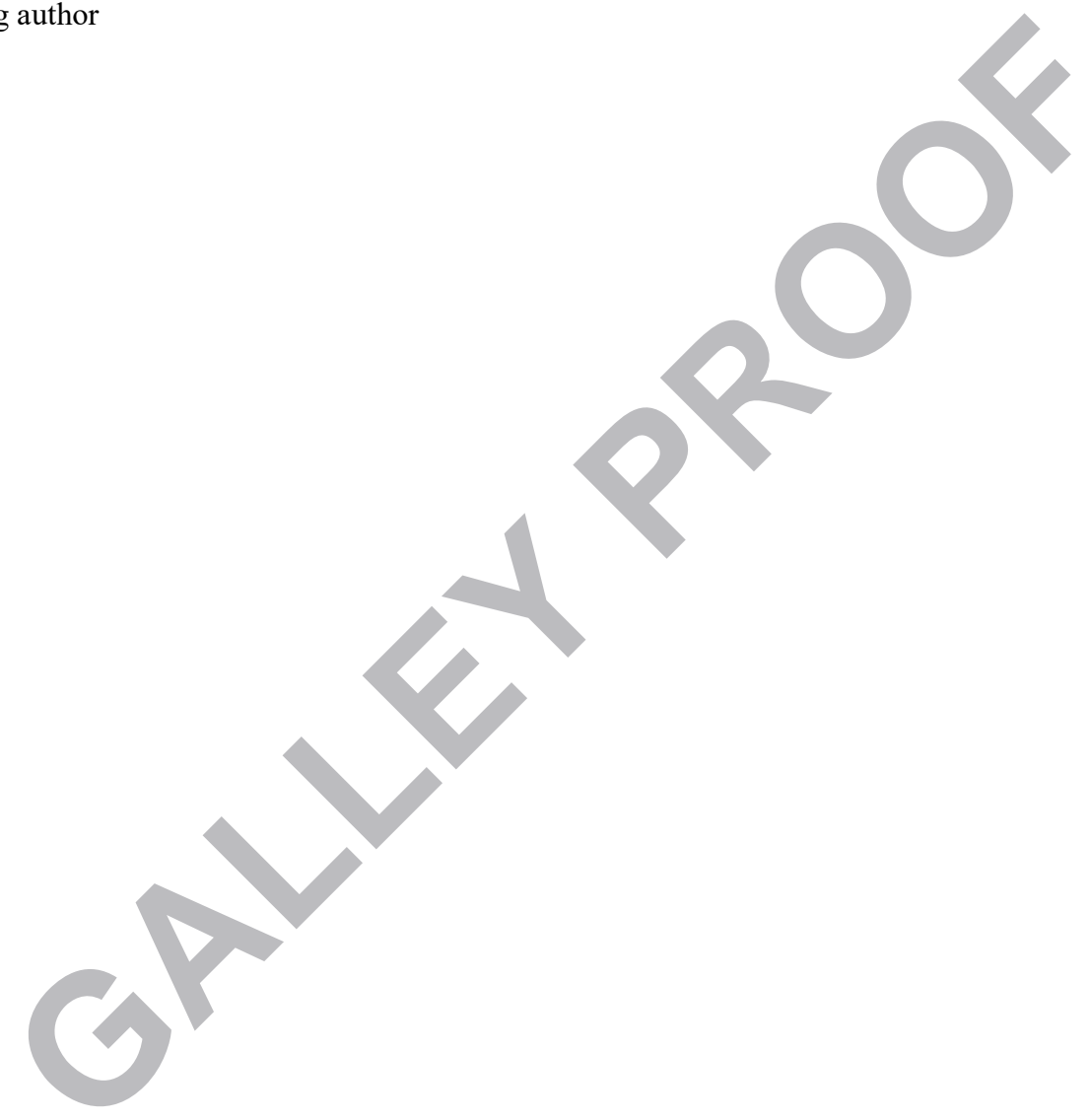

